\title{
Suppression of pulsatile luteinizing hormone secretion by gonadotrophin-releasing hormone antagonist does not affect episodic progesterone secretion or corpus luteum function in ewes
}

\author{
A. S. McNeilly, W. J. Crow and H. M. Fraser \\ $M R C$ Reproductive Biology Unit, University of Edinburgh, Centre for Reproductive Biology, \\ 37 Chalmers Street, Edinburgh EH3 9EW, UK
}

\begin{abstract}
Summary. Progesterone secretion has been observed to be episodic in the late luteal phase of the oestrous cycle of ewes and is apparently independent of luteinizing hormone (LH). This study investigated the effects of suppressing the pulsatile release of $\mathrm{LH}$ in the early or late luteal phase on the episodic secretion of progesterone. Six Scottish Blackface ewes were treated i.m. with $1 \mathrm{mg} \mathrm{kg}^{-1}$ body weight of a potent gonadotrophin-releasing hormone $(\mathrm{GnRH})$ antagonist on either day 4 or day 11 of the luteal phase. Six ewes received saline at each time and acted as controls. Serial blood samples were collected at 10 or $15 \mathrm{~min}$ intervals between 0 and $8 \mathrm{~h}, 24$ and $32 \mathrm{~h}$, and 48 and $56 \mathrm{~h}$ after GnRH antagonist treatment and daily from oestrus (day 0 ) of the treatment cycle for 22 days. Oestrous behaviour was determined using a vasectomized ram present throughout the experiment. Progesterone secretion was episodic in both the early and late luteal phase with a frequency of between 1.6 and 3.2 pulses in $8 \mathrm{~h}$. The GnRH antagonist abolished the pulsatile secretion and suppressed the basal concentrations of LH for at least 3 days after treatment. This suppression of $\mathrm{LH}$, in either the early or late luteal phase, did not affect the episodic release of progesterone. Daily concentrations of progesterone in plasma showed a minimal reduction on days 11 to 14 after GnRH antagonist treatment on day 4, although this was significant $(P<0.05)$ only on days 11 and 13 . There was no effect of treatment on day 11 on daily progesterone concentration, and the timing of luteolysis and the duration of corpus luteum function was unaffected by GnRH antagonist treatment on either day 4 or day 11 . These results indicate that the episodic secretion of progesterone during the luteal phase of the oestrous cycle in ewes is independent of LH pulses and normal progesterone secretion by the corpus luteum can be maintained with minimal basal concentrations of $\mathrm{LH}$.
\end{abstract}

Keywords: LH; progesterone; FSH; corpus luteum; GnRH antagonist; sheep

\section{Introduction}

Although corpus luteum function in terms of progesterone secretion is highly dependent on pulsatile luteinizing hormone (LH) secretion in primates (Fraser et al., 1986), the situation in sheep is not clear. Total removal of LH by hypophysectomy (Kaltenbach et al., 1968; Karsch et al., 1971) or immunoneutralization (Fuller \& Hansel, 1970) results in regression of the corpus luteum in ewes, which can be prevented by treatment with LH (Kaltenbach et al., 1968; Karsch et al., 1971). Although LH receptors are present on both the large and small progesterone-secreting cells which comprise about $50 \%$ of the cells in the sheep corpus luteum (Rodgers et al., 1984), LH 
stimulates progesterone release only from the small cells. The large cells secrete greater amounts of progesterone than small cells under basal conditions and appear to contribute most of the progesterone secreted by the sheep corpus luteum (Alila \& Dowd, 1991; Wiltbank et al., 1991).

We observed pulsatile secretion of progesterone, independent of LH pulses, during the late luteal phase of the cycle (McNeilly \& Fraser, 1987). This was subsequently confirmed and related to a pulsatile or episodic secretion of progesterone by the corpus luteum into the ovarian vein in ewes (Alecozay et al., 1988). We also showed that pulsatile progesterone secretion continued at the end of the luteal phase when pulsatile secretion of $\mathrm{LH}$ had been abolished by chronic treatment of ewes with a gonadotrophin-releasing hormone (GnRH) agonist throughout the luteal phase (McNeilly \& Fraser, 1987). Although this result suggested that the sheep corpus luteum may not require LH pulses for normal luteal function, the GnRH agonist treatment had induced a large release of LH immediately after the start of chronic treatment which may have affected subsequent luteal responsiveness.

The present study was undertaken to examine in detail the effect of abolishing pulsatile $\mathrm{LH}$ secretion by treatment with a GnRH antagonist either in the early or late luteal phase on both daily and short-term pulsatile secretion of progesterone.

\section{Materials and Methods}

\section{Animals and GnRH antagonist treatment}

Scottish Blackface ewes of proven fertility ( 5 years old; $47-53 \mathrm{~kg}$ ) were used in February at the Marshall Building, Roslin, Midlothian. Oestrus was detected in all 18 ewes by running the ewes with a raddled vasectomized ram throughout the course of the experiment. Oestrus was synchronized initially by withdrawing progestagen-impregnated intravaginal pessaries (Intervet Laboratories Ltd, Cambridge, UK) 12 days after their insertion. All ewes displayed behavioural oestrus within $48 \mathrm{~h}$ (designated day 0 ) as determined by the raddled vasectomized rams.

The experiment was carried out in two parts using the same group of six untreated ewes as controls for the GnRH antagonist-treated ewes at both stages of the luteal phase. Ewes treated with GnRH antagonist were given an i.m. injection of $40 \mathrm{mg}$ (approximately $1 \mathrm{mg} \mathrm{kg}^{-1}$ body weight) of the GnRH antagonist Ac-D-p-Cl-Phe ${ }^{1,2}, \mathrm{D}-\mathrm{Trp}^{3}$, D-Arg ${ }^{6}$, D-Ala ${ }^{10}$ GnRH (Org. 30276, batch J; kindly supplied by J. Gielen, Organon, Oss, Holland) in $20 \mathrm{ml}$ sterile water $(\mathrm{pH} 7.0)$ prepared less than i h before injection. This GnRH antagonist was previously shown to inhibit ovulation in $78 \%$ of rats at a dose of $3 \mu \mathrm{g}$ per rat (Horvath et al., 1982).

The eighteen ewes were divided at random into three groups of six ewes. Group 1 ewes were treated with GnRH antagonist on day 4 and group 2 ewes on day 11 of the luteal phase. Group 3 ewes were given an i.m. injection of sterile water on days 4 and 11 and acted as controls for both treatment groups.

Blood samples $(7 \mathrm{ml})$ were taken every day from the jugular vein at 09:00-11:00 h from each ewe starting on day 0 (oestrus) and continuing for 22 days afterwards. In addition, serial blood samples ( $3 \mathrm{ml}$ ) were taken at $15 \mathrm{~min}$ intervals for $12 \mathrm{~h}$ on day 4 from group 1 and 3 ewes and on day 11 from group 2 and 3 ewes after GnRH antagonist injection at 09:00 $\mathrm{h}$. Serial blood samples $(3 \mathrm{ml})$ were then taken at $10 \mathrm{~min}$ intervals for $8 \mathrm{~h}$ from group 1 and 2 ewes between 24 and $32 \mathrm{~h}$ after GnRH antagonist treatment and from groups 1,2 and 3 ewes between 48 and $56 \mathrm{~h}$ after $\mathrm{GnRH}$ antagonist treatment. All serial blood samples were collected through a jugular vein cannula inserted $16 \mathrm{~h}$ before the first sampling period in each group.

All plasma samples were assayed for LH and progesterone and all daily and hourly samples through all serial sampling periods were assayed for FSH.

\section{Radioimmunoassays}

The concentrations of FSH (McNeilly et al., 1976), LH (McNeilly et al., 1986) and progesterone (McNeilly \& Fraser, 1987) in plasma were measured in duplicate using radioimmunoassays described previously and results

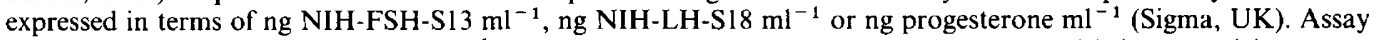
sensitivities were $4,0.2$ and $0.1 \mathrm{ng} \mathrm{ml}^{-1}$ for $\mathrm{FSH}, \mathrm{LH}$ and progesterone, respectively, with intra- and interassay coefficients of variation of $7 \%$ and $11 \%$ for $\mathrm{FSH}, 6 \%$ and $9 \%$ for $\mathrm{LH}$ and $8 \%$ and $10 \%$ for progesterone.

\section{Statistical analysis}

No statistical comparisons were made between the ewes treated with GnRH antagonist on days 4 (group 1) or day 11 (group 2) but each was compared with the control group (group 3) separately. Plasma concentrations of LH, FSH and progesterone in daily samples were compared using analysis of variance followed by Newman Keul's test where 
appropriate. Luteolysis was defined as starting when a sustained drop in plasma concentrations of progesterone occurred leading to plasma concentrations below $0.6 \mathrm{ng} \mathrm{ml}^{-1}$. In serial sampling periods, the characteristics of the LH and progesterone profiles were assessed using the Munro pulse analysis program (Elsevier-Biosoft, Cambridge, UK) with the following parameters: smoothing window $=300 \mathrm{~min}$; minimum pulse interval $=30 \mathrm{~min}$ for $15 \mathrm{~min}$ samples and $20 \mathrm{~min}$ for $10 \mathrm{~min}$ samples; maximum separation between peak and preceding nadir $=45 \mathrm{~min}$ for $15 \mathrm{~min}$ samples and $30 \mathrm{~min}$ for $10 \mathrm{~min}$ samples; rise threshold $=1.75$; Baxter parameters for $\mathrm{LH}: \mathrm{bl}=0.2103, \mathrm{~b} 2=0.0019$, $\mathrm{b} 3=0.0080$ and for progesterone: $\mathrm{b} 1=0.035, \mathrm{~b} 2=0.0088, \mathrm{~b} 3=0.0006$. For progesterone $>80 \%$ of samples had plasma concentrations during the serial sampling period of between 1 and $4 \mathrm{ng} \mathrm{ml}^{-1}$, covering the assay range from 35 to $65 \% \mathrm{~B}: \mathrm{Bo}$, and a coefficient of variation of $7 \cdot 1 \%$. The differences between the controls and treated ewes on each day in these parameters and the mean concentrations of FSH were compared by one-way analysis of variance after transformation of the data to $\left(\log x+\frac{1}{2}\right)$ to standardize the heterogeneity of variance. No analysis was undertaken when treatment resulted in an absence of pulses identifiable using the Munro pulse programme.

\section{Results}

\section{Effect of GnRH antagonist on luteal function, oestrus and daily concentrations of LH and FSH}

Day 4. Treatment with GnRH antagonist on day 4 of the luteal phase had no significant effect on luteal function when assessed by changes in plasma concentrations of progesterone until days 11 and 13 when progesterone was significantly $(P<0.05$, day $11 ; P<0.01$, day 13$)$ lower than in controls (Fig. 1a). Luteal regression, assumed from the drop in progesterone concentration, and oestrus occurred at the same time in control and treated ewes (Fig. la). There was no significant effect on GnRH antagonist treatment on day 4 on daily plasma concentrations of LH (Fig. 1b), but plasma concentrations of FSH were greater in GnRH antagonist treated than in control animals; the difference was significant $(P<0.05$ to $P<0.01)$ on days 7,10 and 13 of the luteal phase, 3,6 and 9 days after treatment.

Day 11. Treatment with GnRH antagonist on day 11 did not affect luteal function in terms of plasma concentration of progesterone, or the plasma concentrations of FSH or LH for 4 days after antagonist treatment (Fig. 1d-f). Oestrus was delayed in all treated ewes until at least day 22, the end of the experiment, 10 days after GnRH antagonist treatment, whereas in control ewes oestrus occurred within 2 days of the onset of luteolysis, assessed by the decline in plasma progesterone. Plasma concentrations of LH were significantly $(P<0.01)$ increased compared with those in treated ewes on days 4 and 5 after GnRH antagonist treatment (Fig. 1d); this increase co-incided with the onset of oestrus in the control ewes and hence represented the preovulatory LH surge.

\section{Concentrations of FSH and pulsatile release of $\mathbf{L H}$ and progesterone}

Day 4. There was no significant effect of treatment with GnRH antagonist on day 4 on plasma concentration of FSH, although concentrations tended to be higher after treatment (Table 1). Representative profiles of the pulsatile secretion of $\mathrm{LH}$ and progesterone for two control and two treated ewes on day 6, 2 days after GnRH antagonist treatment (Fig. 2), and the overall analysis of basal and pulsatile secretion (Table 1) are shown. GnRH antagonist treatment resulted in a significant $(P<0.05)$ suppression of basal concentrations of LH (Table 1) and totally abolished the pulsatile secretion of LH for at least 3 days after treatment (Fig. 2; Table 1). No pulses of LH occurred in treated ewes from the time of GnRH antagonist injection. In contrast, GnRH antagonist treatment had no effect on the basal concentration or the pulsatile release of progesterone (Table 1).

Day 11. There was no effect of GnRH antagonist treatment on the overall plasma concentration of FSH (Table 2, Fig. 1). In contrast, GnRH antagonist treatment resulted in the immediate and sustained suppression of the overall mean plasma concentrations of $\mathrm{LH}(P<0.05$ compared with control) and abolished the pulsatile secretion of LH (Fig. 3; Table 2) in comparison with that of control animals. In contrast, there was no effect of GnRH antagonist treatment on the parameters of pulsatile secretion of progesterone for at least 3 days after $\mathrm{GnRH}$ antagonist treatment on day 11 (Fig. 3; Table 2). 

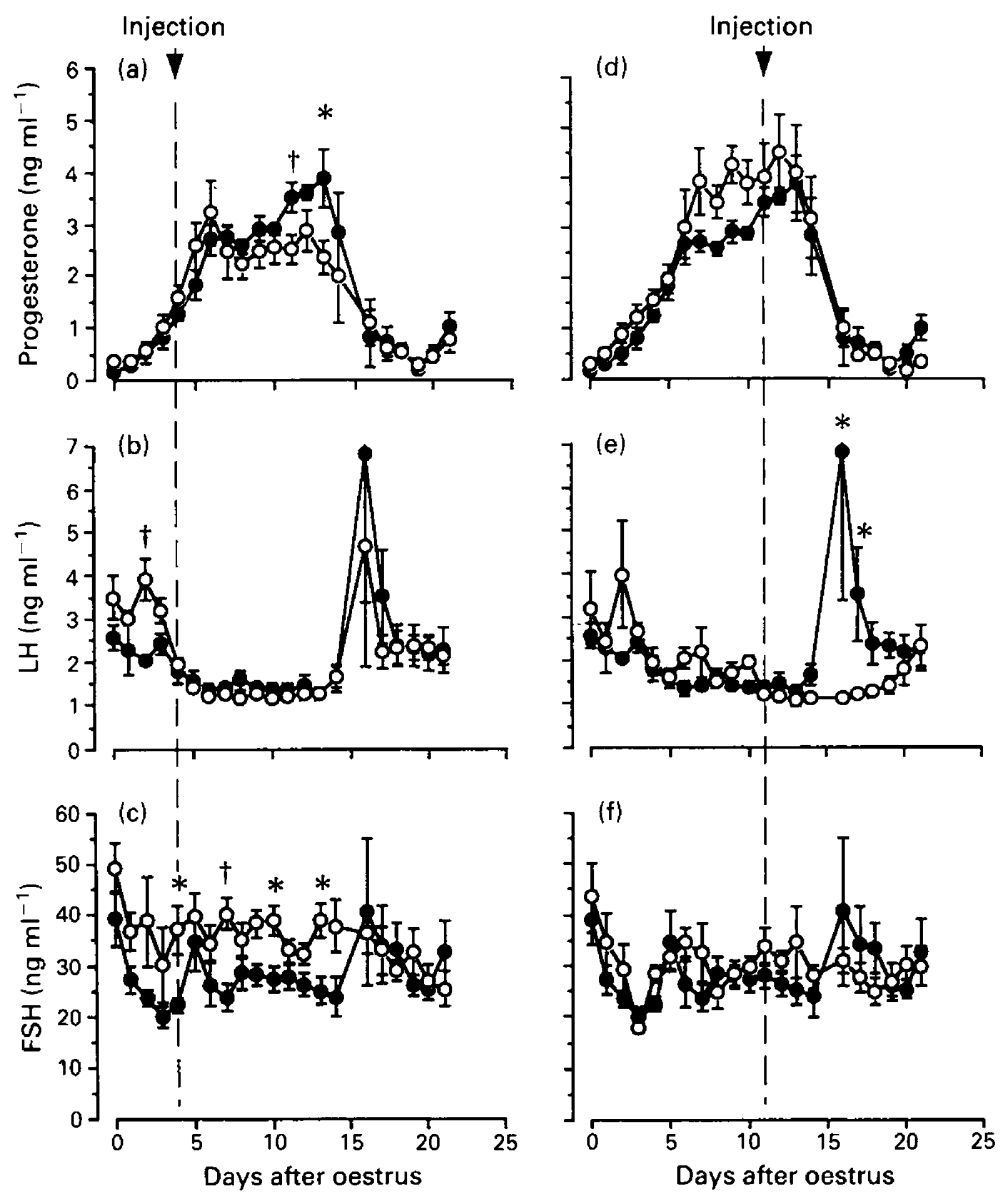

Fig. 1. Effect of the i.m. injection of a gonadotrophin-releasing hormone antagonist on day 4 ((a)-(c)) or day 11 ((d)-(f)) of the oestrous cycle on the plasma concentrations of progesterone ((a) and (d), control ( $\bullet), n=6$; treated $(\mathrm{O}), n=6)$, luteinizing hormone ( $(\mathrm{LH}$; (b) and (e)) and follicle-stimulating hormone ((FSH; (c), (f)) in Scottish Blackface ewes. †Significant difference $(P<0 \cdot 05)$ between control and GnRH-antagonist-treated ewes. *Significant difference $(P<0 \cdot 01)$ between control and GnRH-antagonist-treated ewes.

\section{Relationship between $\mathrm{LH}$ and progesterone pulses}

Results from the serial sampling periods in control ewes on days $4,6,11$ and 13 of the luteal phase were combined around the start of all LH pulses occurring in all control ewes on each of these days so that any relationship between the pulsatile secretion of $\mathrm{LH}$ and changes in the plasma concentrations of progesterone could be determined. The results (Fig. 4) indicated that there was no significant change in the plasma concentration of progesterone in relation to pulses of $\mathrm{LH}$ at any of the stages of the luteal phase examined.

\section{Discussion}

This study shows that, in ewes, concentrations of progesterone in plasma fluctuate in an episodic manner independent of the pulsatile release of $\mathbf{L H}$ and confirms our previous report (McNeilly \& Fraser, 1987) and that of others (Alecozay et al., 1988). We have also shown for the first time that 

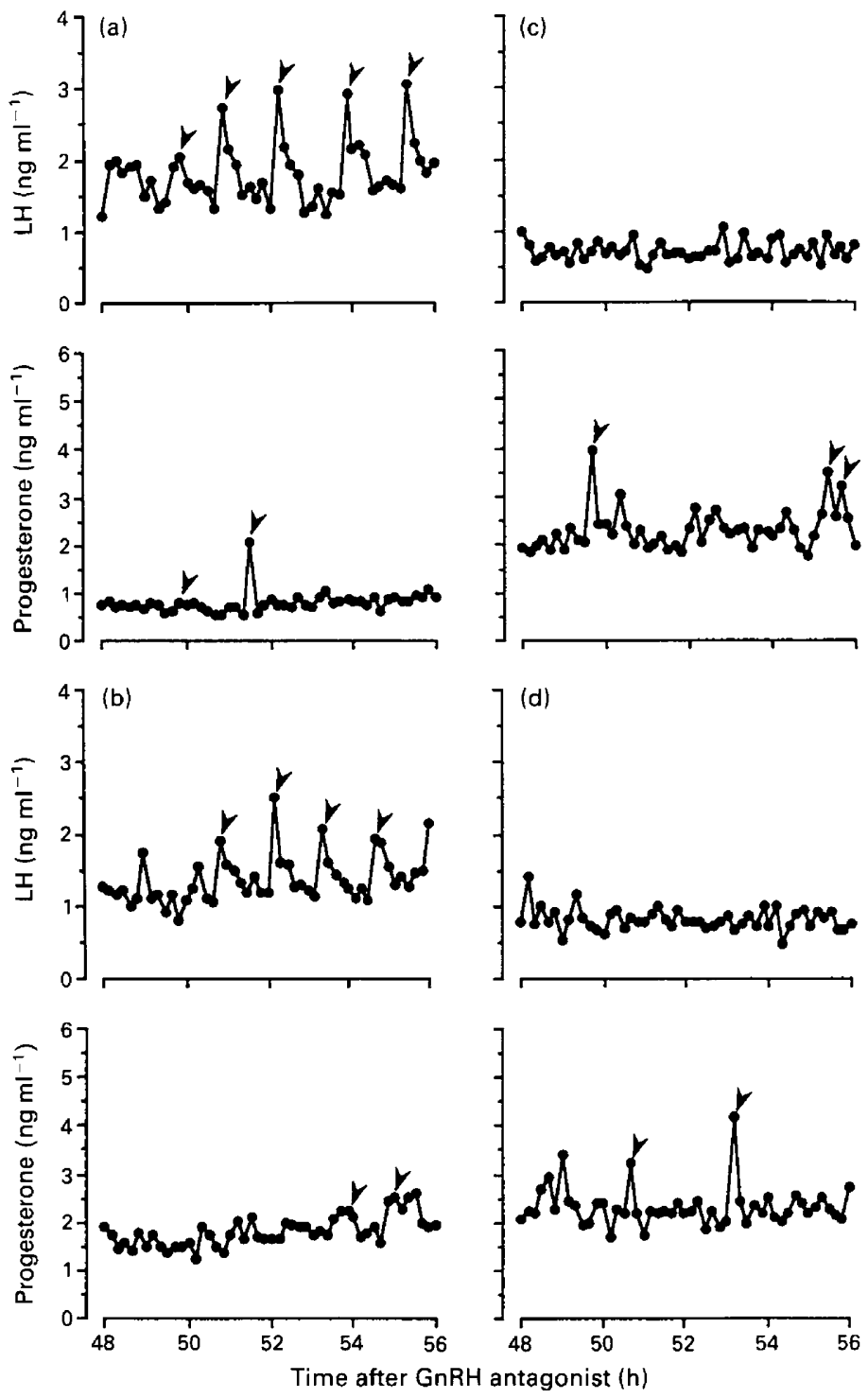

Fig. 2. Individual profiles of the changes in plasma concentrations of luteinizing hormone (LH) and progesterone on day 6 of the luteal phase in two control ewes ((a) and (b)) and two ewes ((c) and (d)) treated on day 4 with a gonadotrophin-releasing hormone antagonist.

abolition of the pulsatile release of LH by treating ewes with a GnRH antagonist had no effect on episodic progesterone secretion during the early luteal phase between days 3 and 6 and the late luteal phase between days 11 and 13. In terms of overall daily progesterone secretion, there was no effect of treatment on day 11 , but after treatment on day 4 plasma concentrations of progesterone were lower between days 11 and 14, although these were significant only on days 11 and 13 . Thus it appears that LH pulses play at most only a minimal role in maintaining progesterone secretion by the corpus luteum in ewes.

Previous studies have confirmed that the sheep corpus luteum requires $\mathrm{LH}$ to maintain progesterone secretion (Kaltenbach et al., 1968; Karsch et al., 1971). The present results do not contradict this since the treatment with GnRH antagonist, although abolishing pulsatile LH 
Table 1. Changes in the mean ( \pm SEM) plasma concentrations of luteinizing hormone (LH), folliclestimulating hormone (FSH) and progesterone in plasma, and pulse frequency and pulse amplitude for LH and progesterone on days 4 and 6 of the luteal phase in control ewes $(n=6)$ and on days 4,5 and 6 in ewes $(n=6)$ treated on day 4 of the luteal phase with a gonadotrophin-releasing hormone $(\mathrm{GnRH})$ antagonist at the start of the sampling period

\begin{tabular}{|c|c|c|c|c|c|c|}
\hline & \multirow[b]{2}{*}{ Parameter } & \multicolumn{2}{|c|}{ Control group } & \multicolumn{3}{|c|}{ GnRH antagonist group } \\
\hline & & Day 4 & Day 6 & Day 4 & Day 5 & Day 6 \\
\hline \multirow[t]{3}{*}{ LH } & $\begin{array}{l}\text { Overall mean } \\
\quad\left(\mathrm{ng} \mathrm{ml}^{-1}\right)\end{array}$ & $1.66 \pm 0.35$ & $1.59 \pm 0.83$ & $0.92 \pm 0.08^{*}$ & $0 \cdot 90 \pm 0 \cdot 11^{*}$ & $0.84 \pm 0 \cdot 15^{*}$ \\
\hline & $\begin{array}{r}\text { Pulse frequency } \\
\text { (pulses in } 8 \mathrm{~h} \text { ) }\end{array}$ & $2 \cdot 60 \pm 1 \cdot 29$ & $2.80 \pm 0.73$ & 0 & 0 & 0 \\
\hline & $\begin{array}{l}\text { Pulse amplitude } \\
\left(\mathrm{ng} \mathrm{ml}^{-1}\right)\end{array}$ & $1.21 \pm 0.26$ & $1.45 \pm 0.16$ & 0 & 0 & 0 \\
\hline FSH & $\begin{array}{l}\text { Overall mean } \\
\quad\left(\mathrm{ng} \mathrm{ml^{-1 }}\right)\end{array}$ & $33.46 \pm 0.29$ & $25 \cdot 18 \pm 3 \cdot 85$ & $44 \cdot 78 \pm 5 \cdot 02$ & $39 \cdot 43 \pm 5 \cdot 03$ & $31 \cdot 39 \pm 2 \cdot 72$ \\
\hline \multirow[t]{3}{*}{ Progesterone } & $\begin{array}{l}\text { Overall mean } \\
\left(\mathrm{ng} \mathrm{ml}^{-1}\right)\end{array}$ & $0 \cdot 83 \pm 0 \cdot 17$ & $2.04 \pm 0.36$ & $0.92 \pm 0 \cdot 17$ & $1.85 \pm 0.47$ & $1.68 \pm 0.27$ \\
\hline & $\begin{array}{l}\text { Pulse frequency } \\
\text { (pulses in } 8 \mathrm{~h} \text { ) }\end{array}$ & $3.20 \pm 0.86$ & $3 \cdot 60 \pm 0 \cdot 81$ & $2.67 \pm 1.41$ & $2.00 \pm 0.68$ & $2 \cdot 67 \pm 0 \cdot 20$ \\
\hline & $\begin{array}{l}\text { Pulse amplitude } \\
\quad(\text { ng ml }\end{array}$ & $0.88 \pm 0 \cdot 15$ & $1.04 \pm 0.14$ & $1 \cdot 30 \pm 0 \cdot 21$ & $1.04 \pm 0.28$ & $1 \cdot 09 \pm 0 \cdot 20$ \\
\hline
\end{tabular}

${ }^{*} P<0.05$ compared with control ewes (ANOVA).

release, did not eliminate the basal secretion of $\mathrm{LH}$. Nevertheless the basal concentrations of $\mathrm{LH}$ in plasma were significantly suppressed in this study indicating that in ewes the corpus luteum can maintain both basal and episodic secretion of progesterone with very much less LH than is normally present throughout the luteal phase. In control ewes there was no clear increase in the plasma concentrations of progesterone after an LH pulse in either the early or late luteal phase as we reported previously (McNeilly \& Fraser, 1987). Treatment of ewes with exogenous LH stimulates the secretion of progesterone (Niswender et al., 1976) and LH stimulates the release of progesterone from small luteal cells in vitro (Fitz et al., 1982; Wiltbank et al., 1991). Thus it is unclear why a more significant increase in progesterone is not seen after an endogenous pulse of LH. This may be due to the apparently relatively minor contribution of the small LH-responsive luteal cells to the overall total amount of progesterone secreted by the corpus luteum. Thus both in the early and late luteal phase suppression of pulsatile $\mathrm{LH}$ release would have a minimal effect on plasma concentrations of progesterone, as confirmed in the present study. The lower plasma concentrations of progesterone on days 11 and 14, after treatment with GnRH antagonist on day 4, suggest a potential role for $\mathbf{L H}$ pulses in programming the development of the corpus luteum during the latter part of the luteal phase, although the effect is not major since plasma concentrations of progesterone were only significantly reduced on two of these days.

Plasma concentrations of FSH were greater in treated than in control ewes after GnRHantagonist treatment on day 4 probably owing to the reduction in ovarian steroid and inhibin secretion that probably followed the suppression of pulsatile LH secretion (Campbell et al., 1990). However, it is unlikely that FSH is involved in the control of progesterone secretion by the sheep corpus luteum since FSH receptors have not been identified on the corpus luteum (Alila \& Dowd, 1991) and suppression of plasma concentrations of FSH throughout the luteal phase by treatment with bovine follicular fluid did not affect plasma concentrations of progesterone (Wallace \& McNeilly, 1985; Brooks et al., 1992).

The cause of the episodic release of progesterone is unknown. Alterations in blood flow in the ovarian vein do not appear to be involved (Collett et al., 1973; Alecozay et al., 1988; Campbell et al., 1990). Whereas there are between 10 and 20 times the number of small LH-responsive than 

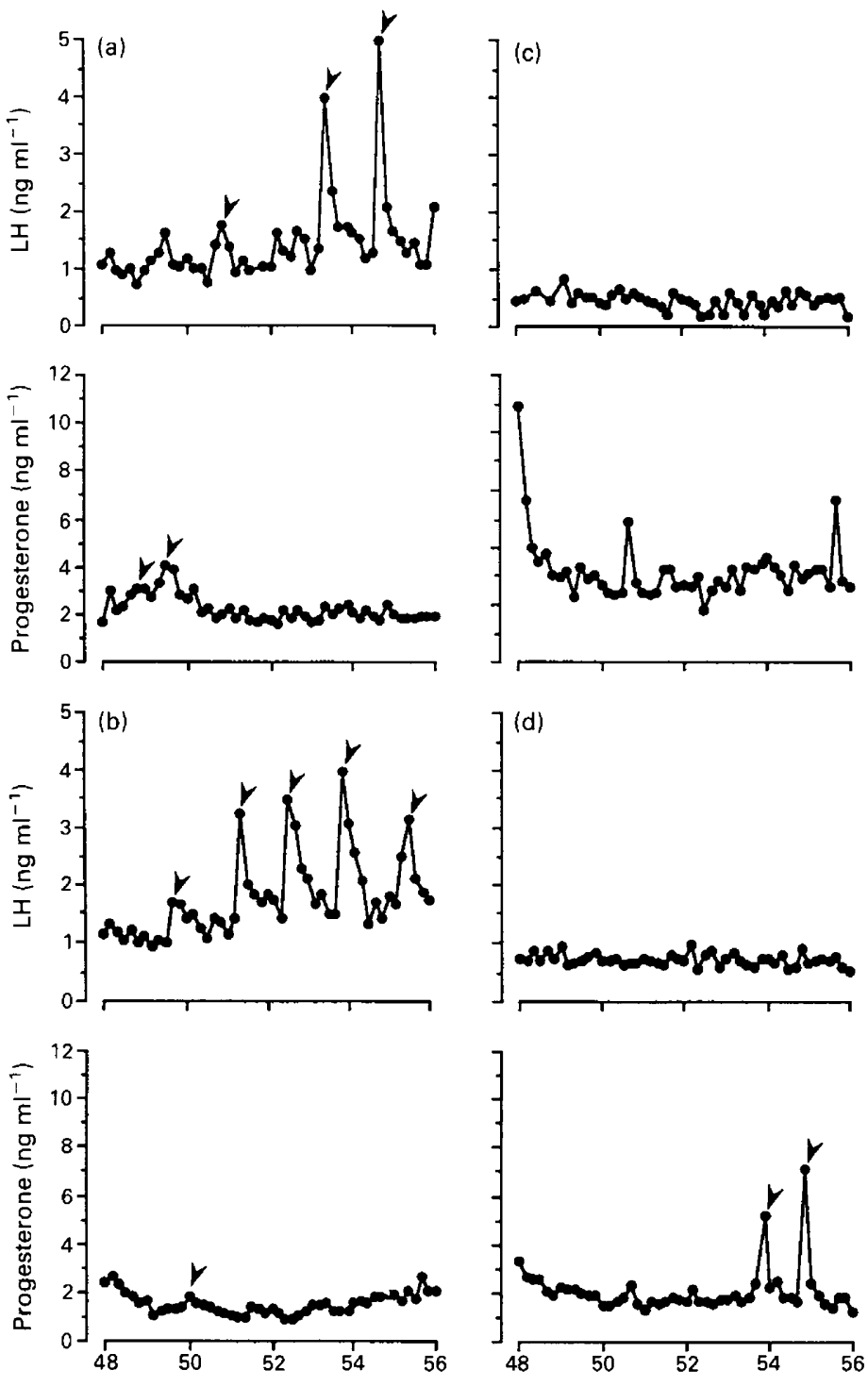

Time after GnRH antagonist (h)

Fig. 3. Individual profiles of the changes in plasma concentrations of luteinizing hormone (LH) and progesterone on day 13 of the luteal phase in two control ewes ((a) and (b)) and two ewes $((c)$ and (d)) treated on day 11 with a gonadotrophin-releasing hormone antagonist.

large non- $\mathrm{LH}$ responsive progesterone secretory cells, these small cells represent less than half of the volume of progesterone-producing cells in the sheep corpus luteum (Rodgers et al., 1984). Furthermore, the large cells produce much greater amounts of progesterone than the small cells via an autonomous, LH-independent mechanism (Alila \& Dowd, 1991; Wiltbank et al., 1991). Thus the source of the episodic release of progesterone appears to lie within the corpus luteum and is apparently not dependent on the pulsatile release of $\mathrm{LH}$.

In this study luteolysis occurred at the same time in both control ewes and ewes treated with GnRH antagonist in the early or late luteal phase. Suppression of the pulsatile release of LH is likely to have disrupted steroid secretion from the ovarian follicle(s) (Campbell et al., 1990) as 
Table 2. Changes in the mean ( \pm SEM) plasma concentrations of luteinizing hormone (LH), folliclestimulating hormone (FSH) and progesterone in plasma, and pulse frequency and pulse amplitude for LH and progesterone on days 11 and 13 of the luteal phase in control ewes $(n=6)$ and on days 11,12 and 13 in ewes $(n=6)$ treated on day 11 of the luteal phase with a gonadotrophin-releasing hormone $(\mathrm{GnRH})$ antagonist at the start of the sampling period

\begin{tabular}{|c|c|c|c|c|c|c|}
\hline & \multirow[b]{2}{*}{ Parameter } & \multicolumn{2}{|c|}{ Control group } & \multicolumn{3}{|c|}{ GnRH antagonist group } \\
\hline & & Day 11 & Day 13 & Day 11 & Day 12 & Day 13 \\
\hline \multirow[t]{3}{*}{ LH } & $\begin{array}{l}\text { Overall mean } \\
\quad\left(\mathrm{ng} \mathrm{ml}^{-1}\right)\end{array}$ & $1.54 \pm 0.29$ & $1 \cdot 54 \pm 0 \cdot 27$ & $0.73 \pm 0.08^{*}$ & $0.69 \pm 0.08^{*}$ & $0.65 \pm 0.08^{*}$ \\
\hline & $\begin{array}{l}\text { Pulse frequency } \\
\text { (pulses in } 8 \mathrm{~h} \text { ) }\end{array}$ & $3 \cdot 20 \pm 0.58$ & $2 \cdot 8 \pm 0.58$ & 0 & 0 & 0 \\
\hline & $\begin{array}{l}\text { Pulse amplitude } \\
\quad\left(\mathrm{ng} \mathrm{ml}^{-1}\right)\end{array}$ & $2.08 \pm 0.28$ & $1 \cdot 74 \pm 0 \cdot 24$ & 0 & 0 & 0 \\
\hline FSH & $\begin{array}{l}\text { Overall mean } \\
\quad\left(\mathrm{ng} \mathrm{ml}^{-1}\right)\end{array}$ & $31 \cdot 03 \pm 3 \cdot 21$ & $25 \cdot 36 \pm 2 \cdot 99$ & $34.96 \pm 2.44$ & $29 \cdot 40 \pm 1 \cdot 98$ & $27 \cdot 25 \pm 2 \cdot 52$ \\
\hline \multirow[t]{3}{*}{ Progesterone } & $\begin{array}{l}\text { Overall mean } \\
\quad\left(\text { ng ml } l^{-1}\right)\end{array}$ & $2.44 \pm 0.25$ & $3 \cdot 16 \pm 0 \cdot 55$ & $3 \cdot 32 \pm 0 \cdot 64$ & $4 \cdot 55 \pm 0 \cdot 82$ & $3.09 \pm 0.79$ \\
\hline & $\begin{array}{l}\text { Pulse frequency } \\
\text { (pulses in } 8 \mathrm{~h} \text { ) }\end{array}$ & $2.60 \pm 0.68$ & $2 \cdot 00 \pm 0 \cdot 29$ & $2 \cdot 20 \pm 0 \cdot 48$ & $1 \cdot 67 \pm 0 \cdot 33$ & $1.83 \pm 1.07$ \\
\hline & $\begin{array}{l}\text { Pulse amplitude } \\
\quad\left(\mathrm{ng} \mathrm{ml}^{-1}\right)\end{array}$ & $1 \cdot 45 \pm 0 \cdot 26$ & $1 \cdot 41 \pm 0.32$ & $1.95 \pm 0.35$ & $1 \cdot 86 \pm 0 \cdot 15$ & $1.99 \pm 0.88$ \\
\hline
\end{tabular}

${ }^{*} P<0.05$ compared with control ewes (ANOVA).

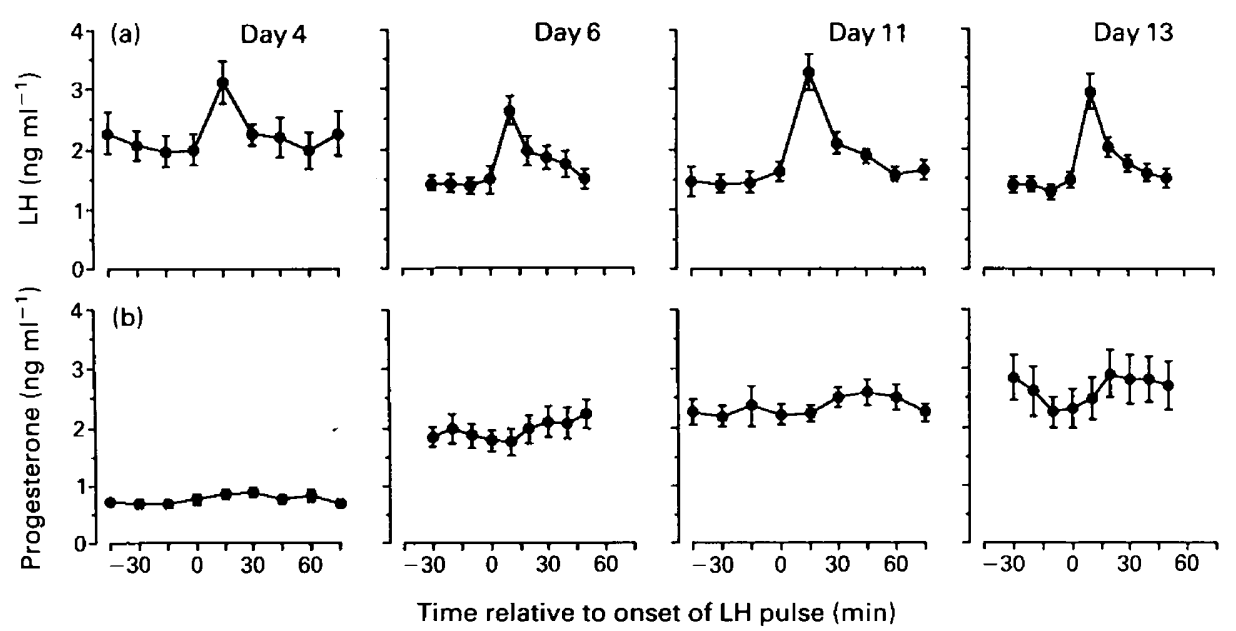

Fig. 4. Changes in the mean ( \pm SEM) plasma concentrations of (a) $\mathrm{LH}$ and (b) progesterone centred around spontaneous pulses of LH on days 4 ( $n=13$ pulses), 6 ( $n=14$ pulses), 11 ( $n=16$ pulses) and $13(n=14$ pulses) of the luteal phase in control ewes.

indicated by the delay in the onset of oestrus for at least 7 days after GnRH antagonist treatment on day 11. This suggests that ovarian follicle components may play only a minor role in the oxytocin mediated control of prostaglandin-induced luteolysis (Flint et al., 1990; Silvia et al., 1991).

In summary, the present results indicate that progesterone is released from the corpus luteum of sheep in an episodic manner independent of the pulsatile secretion of $\mathrm{LH}$, and that suppression of pulsatile LH release for at least three days in either the early or late luteal phase does not affect either episodic or daily progesterone secretion or influence the timing of luteolysis. The 
corpus luteum in ewes can be sustained by basal concentrations of LH significantly lower than normally occur in the luteal phase. These results are in contrast to results from studies of primates in which the secretion of progesterone depends on the pulsatile release of LH (Fraser et al., 1986).

We thank N. Anderson and G. Cowen for skilled technical assistance, the NIDDK and the National Hormone and Pituitary Program (University of Maryland School of Medicine) and L. E. Reichert, Jr, Albany University for the provision of some radioimmunoassay reagents, J. Gielen, Organon, Holland for the GnRH antagonist, T. McFetters and E. Pinner for preparation of the figures and M. Stevenson for typing the manuscript.

\section{References}

Alecozay, A.A., Selcer, K.W., Clark, J.R., Burns, J.M., Norman, R.L., Niswender, G.D. \& Leavitt, W.W. (1988) Pattern of ovarian progesterone secretion during the luteal phase of the ovine oestrous cycle. Biology of Reproduction 39, 287-294.

Alila, H.W. \& Dowd, J.P. (1991) The control of corpus luteum function in domestic ruminants. In Oxford Reviews of Reproductive Biology, pp. 203-237. Ed. S. R. Milligan. Oxford University Press, Oxford.

Brooks, J., Crow, W.J., McNeilly, J.R. \& McNeilly, A.S. (1992) Relationship between gonadotrophin subunit gene expression, gonadotrophin-releasing hormone receptor content and pituitary and plasma gonadotrophin concentrations during the rebound release of FSH after treatment of ewes with bovine follicular fluid during the luteal phase of the cycle. Journal of Molecular Endocrinology 8, 109-118.

Campbell, B.K., McNeilly, A.S., Picton, H.M. \& Baird, D.T. (1990) The effect of a potent GnRH antagonist on ovarian secretion of oestradiol, inhibin and androstenedione and the concentration of $\mathrm{LH}$ and FSH during the follicular phase of the sheep oestrous cycie. Journal of Endocrinology 126, 377-384.

Collett, R.A., Land, R.B. \& Baird, D.T. (1973) The pattern of progesterone secretion by the autotransplanted ovary of the ewe in response to ovine luteinizing hormone. Journal of Endocrinology 56, 403-411.

Fitz, T.A., Mayan, M.H., Sawyer, H.R. \& Niswender, G.D. (1982) Characterization of two steroidogenic cell types in the ovine corpus luteum. Biology of Reproduction 27, 703-711.

Flint, A.P.F., Sheldrick, E.L., McCann, T.J. \& Jones, D.S.C. (1990) Luteal oxytocin: characteristics and control of synchronous episodes of oxytocin and $\mathrm{PGF}_{2 \alpha}$ secretion at luteolysis in ruminants. Domestic Animal Endocrinology 7, 111-124.

Fraser, H.M., Abbott, M., Laird, N.C., McNeilly, A.S., Nestor, Jr, J.J. \& Vickery, B.H. (1986) Effects of an LH-releasing hormone antagonist on the secretion of LH, FSH, prolactin and ovarian steroids at different stages of the luteal phase in the stumptailed macaque (Macaca arctoides). Journal of Endocrinology 111, 83-90.

Fuller, G.B. \& Hansel, W. (1970) Regression of the sheep corpus luteum after treatment with antibovine luteinizing hormone. Journal of Animal Science 31, 99-103.
Horvath, A., Coy, D.H., Nekola, M.V., Coy, E.J., Schally, A.V. \& Teplan, I. (1982) Synthesis and biological activity of LH-RH antagonists modified in position 1. Peptides 3, 969-971.

Kaltenbach, C.C., Graber, J.W., Niswender, G.D. \& Nalbandov, A.V. (1968) Luteotrophic properties of some pituitary hormones in nonpregnant or pregnant hypophysectomized ewes. Endocrinology 82, 818-824.

Karsch, F.J., Roche, J.F., Noveroske, J.W., Foster, D.L., Norton, H.W. \& Nalbandov, A.V. (1971) Prolonged maintenance of the corpus luteum function of the ewe by continuous infusion of luteinizing hormone. Biology of Reproduction 4, 129-136.

McNeilly, A.S. \& Fraser, H.M. (1987) Effect of gonadotrophin-reieasing hormone agonist-induced suppression of LH and FSH on follicle growth and corpus luteum function in the ewe. Journal of Endocrinology 115, 273-282.

McNeilly, J.R., McNeilly, A.S., Walton, J. \& Cunningham, F.J. (1976) Development and application of a heterologous radioimmunoassay for ovine folliclestimulating hormone. Journal of Endocrinology 70, 69-79.

McNeilly, A.S., Jonassen, J.A. \& Fraser, H.M. (1986) Suppression of follicular development after chronic LHRH immunoneutralization in the ewe. Journal of Reproduction and Fertility 76, 481-490.

Niswender, G.D., Reimers, T.J., Diekman, M.A. \& Nett, T.M. (1976) Blood flow: a mediator of ovarian function. Biology of Reproduction 14, 64-81.

Rodgers, R.J., O'Shea, J.D. \& Bruce, N.W. (1984) Morphometric analysis of the cellular composition of the ovine corpus luteum. Journal of Anatomy 138, $757-769$.

Silvia, W.J., Lewis, G.S., McCracken, J.A., Thatcher, W.W. \& Wilson, L., Jr (1991) Hormonal regulation of uterine secretion of prostaglandin F2 $\alpha$ during luteolysis in ruminants. Biology of Reproduction 45, 655-663.

Wallace, J.M. \& McNeilly, A.S. (1985) Increase in ovulation rate after treatment of ewes with bovine follicular fluid in the luteal phase of the oestrous cycle. Journal of Reproduction and Fertility 73, 505-515.

Wallace, J.M. \& McNeilly, A.S. (1986) Changes in FSH and the pulsatile secretion of LH during treatment of ewes with bovine follicular fluid throughout the luteal 
phase of the oestrous cycle. Journal of Endocrinology 111, 317-327.

Wiltbank, M., Diskin, M.G. \& Niswender, G.D. (1991)

Differential actions of second messenger systems in the corpus luteum. Journal of Reproduction and Fertility Supplement 43, 65-75.

Received 3 February 1992 